\title{
Underground houses - systematic approach toward underground construction of living space.
}

\author{
Lulzim Beqiri ${ }^{1}$, Zejnulla Rexhepi ${ }^{2}$, Mimoza Sylejmani $^{2}$, Besian Sinani $^{2}$ \\ UBT - Higher Education Institution, Prishtinë, Kosovë, \\ \{lbeqiri ${ }^{1}$; zejnulla.rexhepi ${ }^{2}$; mimoza.sylejmani², \\ besian.sinani $\left.{ }^{2}\right\} @$ ubt-uni.net
}

\begin{abstract}
The urgent need for energy consumption reduction and trends of global warming leads toward exploring possibilities to "hide" living space from explosion to climate changes as a result of global warming. This paper aims to present benefits of underground houses, underground living space. Housing is elementary process of mankind life that was performed from the existence of life in different forms, shapes, levels and social developments. House, as one used to get protected by phenomena of the nature, historically used in different shapes, levels and materials, created mentality that one percept as protective, and isolated space, for life activities. This paper treat possibilities, and priorities, of underground housing and construction of underground house in current development of technology, climate development impact, current development of mentality of society and approach of society toward energy efficiency, as underground house is one of the contribution. Paper as well analyze applicable standards and current legislation in Kosova for underground construction and housing.
\end{abstract}

Keywords: Underground house, housing, living space, efficiency

The urgent need for energy consumption reduction and trends of global warming leads toward exploring possibilities to "hide" living space from being exposed to climate changes as a result of global warming. Following we will present benefits of underground houses, underground living space.

Housing is elementary process of mankind life that was performed from the existence of life in different forms, shapes, levels and social developments.

House, as one used to get protected by phenomena of the nature, historically used in different shapes, levels and materials, created mentality that one percept as protective, and isolated space, for life activities.

This paper treat possibilities, and priorities, of underground housing and construction of underground house in current development of technology, climate development impact, current development of mentality of society and approach of society toward energy efficiency, as underground house is one of the contribution. Furthermore, as well analyze applicable standards and current legislation in Kosova for underground construction and housing.

The following aspect will be analyzed and explored:

- Function

- Standards-Legislation-Construction Permit

Urban areas in Kosovo are characterized by a horizontal extension of individual housing in a very large percentage compared to the collective one. Individual and collective housing ratio within the urban area is: $90 \%$ individual housing, $10 \%$ collective housing in most of the cities of Kosovo [1, p.33]. 


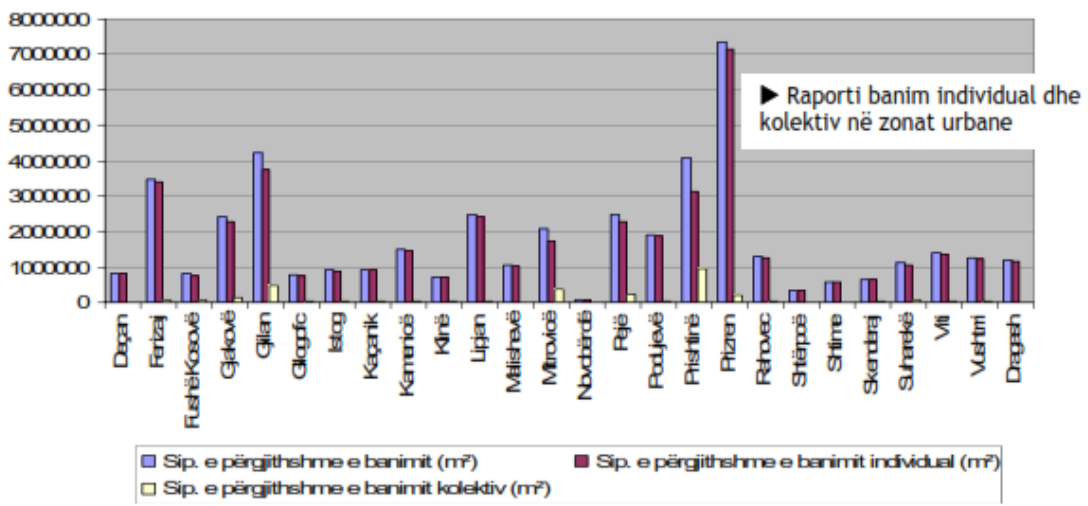

Fig. 1 Irrational usage of Space - Individual and Collective Housing Ratio in Urban Areas Source: Kosovo Spatial Plan - Spatial Development Strategy 2010-2020 [1, p.33]

A questionnaire has been conducted with residents of the Republic of Kosovo over the age of 18 to understand their preferences regarding resident units where they prefer to live and other questions related to this research.. Sample Size for questionnaires is set based on the Sample Size Calculator [2], where the sample size is determined to be 600 .

Based on the research results it turns out that $75 \%$ of residents in Kosovo prefer to live in individual residential houses, while $20 \%$ in residential multistore buildings, while $2 \%$ in others (Fig.2)

Where did you prefer to live (Fig. 1)?

a) Multistore residential buildings;

b) House

c) Other.

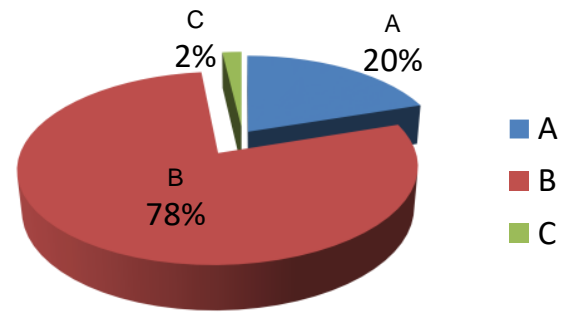

Fig. 2. Results related to type of housing

This is one of the reasons why research is focused at the treatment of individual residential buildings, by targeting Underground Houses. The houses have been treated in some respects as:

- The functional aspect,

- The way of building,

- The energy efficiency,

- $\quad$ The legislative aspect (standards and permit). 
Kosovo is characterized as a hilly and mountainous country, with long and cold winters and warm summers [3], so the construction of underground houses and application of underground concept of living would be beneficial for the residents of our country, knowing that the underground buildings are determined as low cost in terms of energy. As the global warming also affect Kosovo is another reason for this type of building and living style. Kosovo is characterized, among the poorest countries in the region (Table 1), therefore the application of such a construction system would be more than welcome (it would bring benefits to our citizens).

Table 1. Unemployment in Kosova in comparison with other countries in the region Source: Spatial Plane of Kosovo- Strategy of Spatial development 2010-2020, translated by the author [1, p. 111]

\begin{tabular}{|c|c|c|c|c|c|c|}
\hline & $\begin{array}{c}\text { Serbia and } \\
\text { Montenegro }\end{array}$ & Macedonia & Bulgaria & Albania & Romania & Kosovo \\
\hline Scale & $30 \%$ & $24 \%$ & $12.6 \%$ & $30 \%$ & $44.5 \%$ & $50.3 \%$ \\
\hline
\end{tabular}

\section{Functional analyses of underground residential housing}

Analyses in the functional aspect is done based on the possibilities that the construction system allows, are suitable, for this type of construction, and the mentality that the resident of Kosovo lives with.

The question "where you prefer to live" helped us to choose the location we would be focused for our study.

Where do you prefer to live (Fig.3)?

a) In the city center;

b) In the suburbs of the city;

c) In the village;

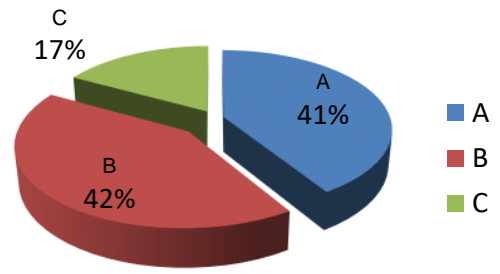

Fig. 3. Results for resident's preference for living location

The results show that inhabitants-residents prefere peripheral parts of the city, where the peripheral parts of the main cities of our country are usually characterized by a steep terrain, such as Dragodan, Veternik and others parts of Prishtina, Tabje, Zatra, Kapeshnica, in Peja, and other main cities in Kosova too.

Considering fact that in our mentality there is still a so-called "hospitality", the clear definition of the quiet and noisy area would be more than necessary. In the case of the one floor houses, 
this separation would be realized through separation unit, which in the cases of the underground houses could appear as a roof lighting element, for the lighting of the bedrooms,

While the part of the living room, the kitchen and the dining room, can have lightning using the slope terrain. From all the frontal surfaces made of glass, the greenery will be reflected by merging the residential units with yard greenery Fig. 5.

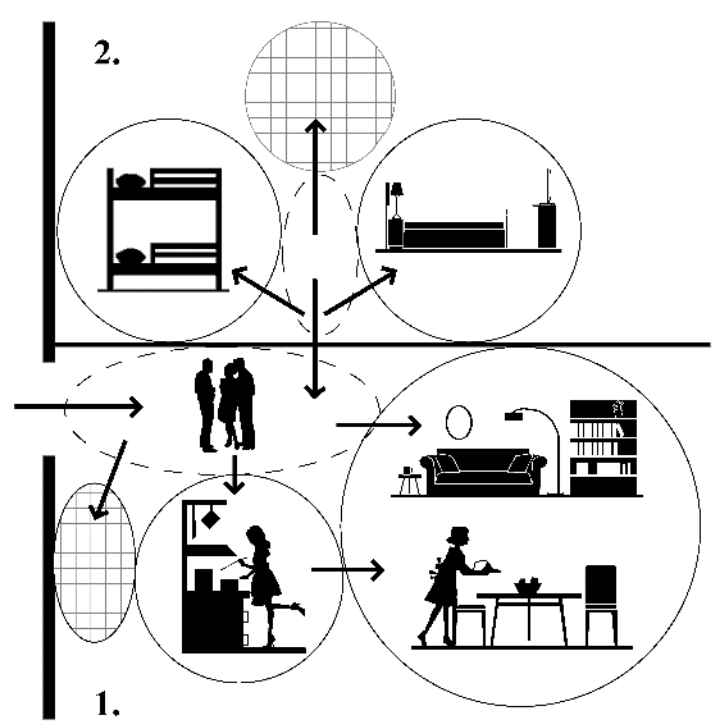

Fig. 5. Division of quiet and noisy zone

At the Fig. 6 .and Fig. 7, are presented through section of terrain and houses characteristics of the location and positioning of underground houses. 


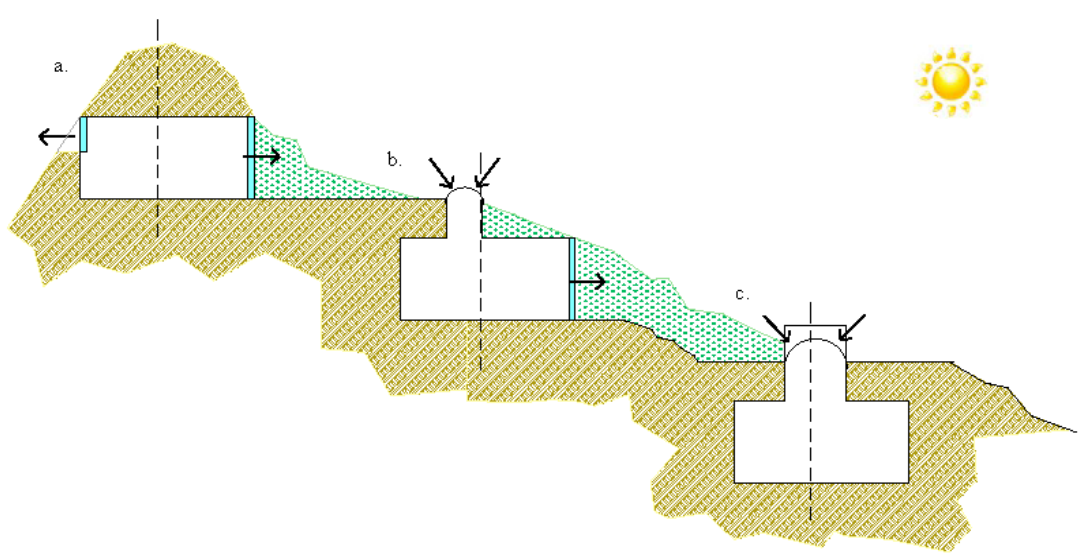

Fig. 6. Types of underground houses location-vertical section

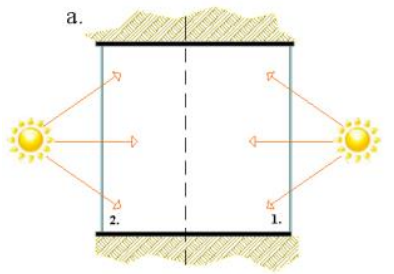

1. Noisy area
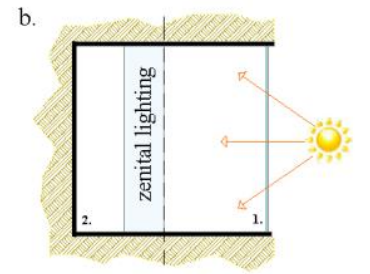

1. Noisy area

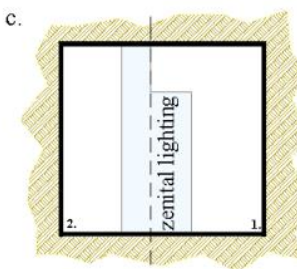

1. Noisy area
2. Quiet area

Fig.7. Types of underground houses location-horizontal section

a.

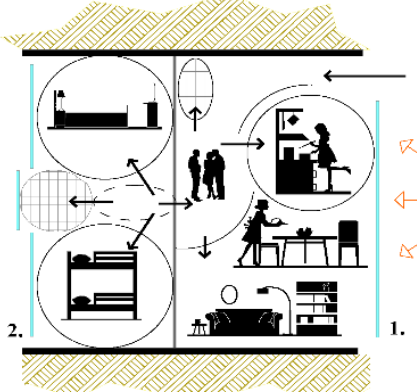

Fig.8 presents type a) underground houses that in fact is most suitable type related to natural lightning.

This tip applies to the highest point of the hilly terrain, and its priority is that the quiet and noisy area can be displaced depending on the position of the dwellings on the horizon sides.

1. Noisy area

2. Quiet area

Fig.8 Type a) Functional aspect 
At the Fig. 9 is presented the second type of underground housing, which allows the unit to have natural lightning only on one side, while the zenithal (roof) lightening is used for the quiet area of the housing unit. The problem of this type is when the housing unit is necessarily oriented towards the north.

Fig.9. Type b) Functional Aspect

c.

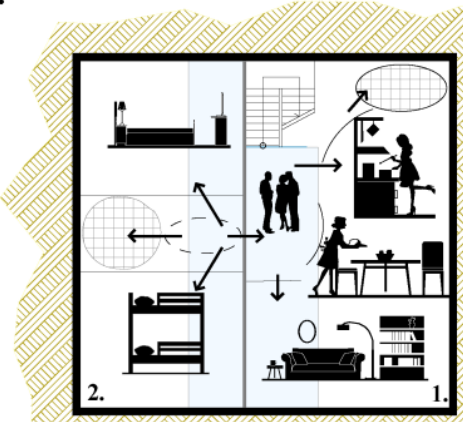

1. Noisy area

2. Quiet area

Fig.10. Type c) Functional aspect b.

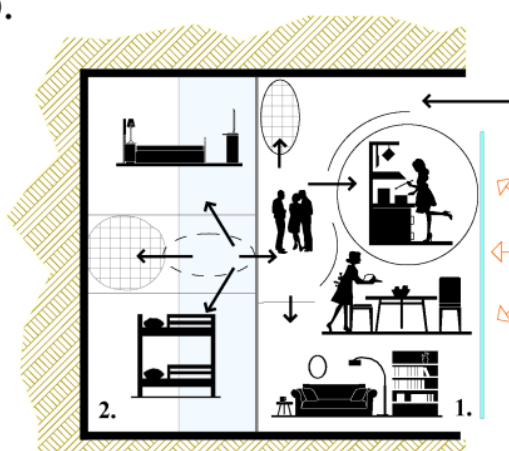

1. Noisy area

2. Quiet area

\begin{abstract}
The most challenging type of underground houses is Type c), which is presented in Fig.10. In this case, the entire housing units this case, the entire housing units
are using the zenithal (roof) lightning that means that there is enough natural lights but no enough insolation. .
\end{abstract}




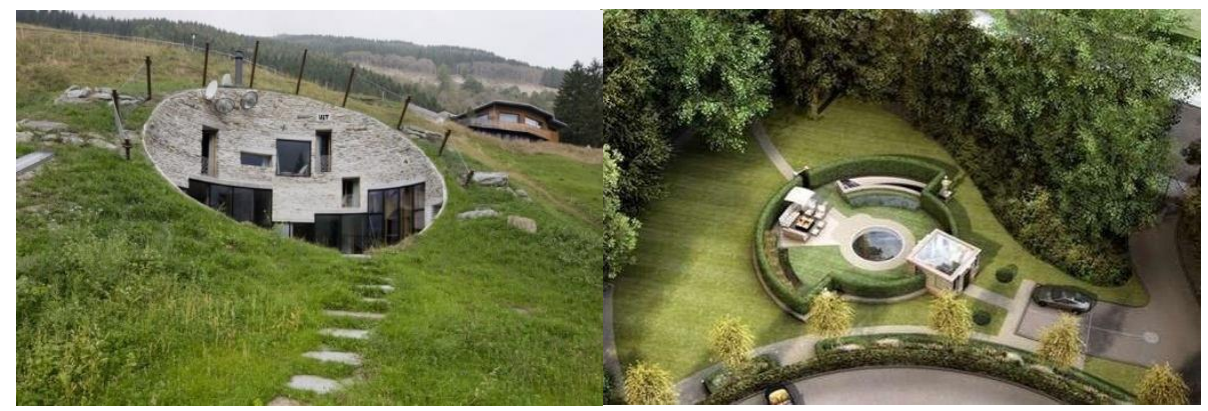

Fig. 11. Type $b$ and type $c$ or underground residential unit-house Source; https://selfbuild.ie/project/the-underground-house/, The Underground House https://www.trendir.com/house-design/underground-homes/, Luxury Underground Mansion in England with waterslide feature, Last visited; 20.10.2017

\section{Underground construction stability}

Based on current underground construction concept (tunnels. Basement etc.) the underground construction are more sustainable structures and suffer appreciably lessdamage than surface structures. [5]

Underground facilities constructed in soils can be expected to suffer more damage compared to openings constructed in competent rock. [6].

The underground structure result to be more preferable related to safety of structure in earthquake and other related disaster that can generate terrain shaking situation [8]. Preferred shape for underground residential unit is "arch" form that is more sustainable for underground construction.

\section{Standards-Legislation-Construction Permit}

Construction Law 04/L-110 of date 31.05.2012, respectively article 15 determines following construction categories:

1.1. Category I - low risk construction;

1.2. Category II - medium risk construction

1.3. Category III - high risk construction and construction of national interest.

Ministry of planning in 2014 issued a design regulation for multistory dwellings under the name "Regulation no. 04/2014 on the minimum technical norms for residential multistory dwellings Article 6 of this regulation says:

"1. Placement-location of the apartment in the basement is not allowed unless one of its facades is located above the ground level and in the immediate vicinity there is a neighboring building, a protective wall or similar element in distance of $6 \mathrm{~m}$ " [8].

While in point 3 it says,: "In the case of multistory dwellings that have a courtyard or atrium, it is not allowed to plan a living room orientation if the distance between the inner facades is below 15m." [8].

From the above points we conclude that this regulation does not foresee complete underground constructions, but only the combined ones - on and below the ground.

In 2017, MESP has begun the amendment and amendment of this regulation, which on 04/2017 has approved the new regulation which basements determines as follows: 
"Basement - a floor located below ground or basement where more than $50 \%$ of its volume is entered below ground level"

In the last 17 years, the Pristina Municipality did not accept any single request for underground construction, except those cases where the terrain was largely steep and most of the floors were named as basements. If any of municipalities receive a request for construction of underground house in the Republic of Kosovo, they should draft a special regulation to address this permit request based on the practices of the region by respecting local legislation and professional aspect (design and construction).

The investor will face problems on getting permit as law on design and construction in Kosova did not foresee any possibility of having underground dwelling construction and procedure to issue permit for such cases

\section{Conclusion}

Based on above analyses and results it is visible that individual residential unit is more acceptable for living for most of the inhabitants and therefore it is necessary to be more focused on individual residential units. Global warming and climate change influence house to "hide" from external climate factor (especially temperature). A part from several benefits, there are some difficulties on underground house design. The functional arrangement of the residential unit, underground located, create some difficulties on natural resource usage and perception, but as well generate several more benefits that are taking part on global energetic issues to be solved in the future. Functional arrangement may have some changes that may not affect commodity of functional relation and usage of specific residential unit. Furthermore energetic exchange between ground and underground residential unit create great opportunity for energetic independence. Kosova currently has no set of standards for underground residential building and therefore no permit can be issued for this type of residential unit. It is necessary to raise the issue as construction of underground residential unit remains as best current response to global warming and energy consumption reduction.

\section{To be considered}

- Create standards -based on local (Kosovo) climate factors

- Analyze social and health parameters of underground life condition

- Analyze of energetic benefits

\section{References}

1. Plani Hapesinor i Kosoves, strategjia e zhvillimit hapesinor 2010-2020-Kosova shtepia jone-Qeveria e Kosoves-Ministria e Mjedisit dhe Planifikimit Hapesinor, Prishtine, Qershor 2010, http://www.kryeministri-

ks.net/repository/docs/Plani_Hapesinor_i_Kosoves_2010-2020_shq.pdf), 09.09.2016

2. (Creative Resarch Systems, https://www.surveysystem.com/sscalc.htm, (last visited 2 August 2017)

3. Vleresimi i varferise ne Kosove; Enti i statistikave te Kosoves, 3 Tetor 2007, http://ask.rks-gov.net/media/2727/vleresimi-i-varferise-ne-kosove-vellimi-ii.pdf; 25.09.2017)

4. Regulation MESP No-04/2014 for minimum technical standards for residential building in condominium and spaces in their function. (https://gzk.rks-gov.net; 20.10.2017) 
5. Stevens, P.R., 1977. A review of the effects of earthquakes on underground mines. United States Geological Survey Open File Report 77313. US Energy Research and Development Administration, Reston, VA.

6. Sharma, S., Judd, W.R., 1991. Underground opening damage from earthquakes. Eng. Geol. 30,

7. Hashash, Y.M.A., Park, D., 2001. Non-linear one-dimensional seismic ground motion propagation in the Mississippi Embayment. Eng. Geol. 62 1 Ž. 3, 185206

8. Construction Law $04 / \mathrm{L}-110$ of date 31.05 .2012 